
and Aromatic Plants

An International Journal

ISSN: 2619-9645 | e-ISSN: 2667-5722

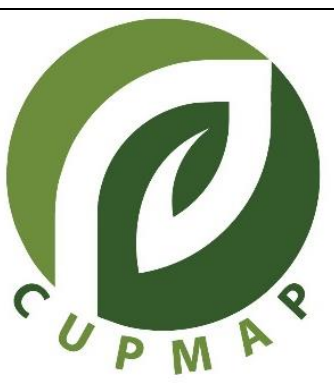

\title{
A Study on Antioxidant and Antimicrobial Activity of Ferulago galbanifera Species
}

\author{
Alican Bahadir SEMERCI, (iD) Melek GULER, $\underline{\text { Kenan TUNC* }}$ (iD \\ Department of Biology, Faculty of Arts and Science, Sakarya University, Sakarya-Turkey \\ *Corresponding author : ktunc@sakarya.edu.tr
}

https://doi.org/10.38093/cupmap.709931

Received : 26/03/2020 Accepted : 27/06/2020

\begin{abstract}
In this work, antimicrobial effects of the root, stem, leaf and flower parts extracts with ethanol and acetone of Ferulago galbanifera species against Escherichia coli, Staphylococcus epidermidis, Enterococcus faecalis Candida albicans, Bacillus subtilis, Pseudomonas aeruginosa, Staphylococcus aureus, Salmonella typhimurium strains were investigated by using the disc diffusion method. In addition to that, antioxidant activity of F. galbanifera ethanolic extracts was measured using the DPPH method, as well as their total phenolic content using the Folin-Ciocalteu's phenol reagent technique. To our results, ethanolic extracts of leaf from $F$. galbanifera were found to have antimicrobial effect against the all microorganisms, whereas the acetonic extracts of leaf has shown antimicrobial effects to some microorganisms other than Staphylococcus epidermidis, E. faecalis, C. albicans species. Extracts obtained from the root and the flower parts of the plant had no antimicrobial effect on the test microorganisms. The antioxidant activity level was found to be in the following order (from the highest to the lowest): flower, leaf, stem and rood; 16.32 , $215,244,323(\mu \mathrm{g} / \mathrm{mL})$, respectively. The highest total phenolic content obtained from the parts of the plant F. galbanifere was for the root, while the lowest was for its leaf part.
\end{abstract}

Key Words: Ferulago galbanifera, Antibacterial, Antioxidant

(c) CUPMAP. All rights reserved.

\section{Introduction}

Genus of Ferulago W. Koch (Apiaceae) is represented by 34 species, amongst them 19 are endemic in Turkey (Saya et. al. 2012). Since the roots and fruits of the Ferulago species contain secretion agent out of essential oil, resin and gum, they have a distinct odour. Their usage and contents are similar to those of Ferula species known publicly as the same name and they (Ferulago species) are being used as aphrodishiac, tonic and digestive agents as well as to heal hemoroids and ascarids in folk medicine (Akalın 1999; Başer et. al. 2002). Ferulago is also used as a spice especially in salads for its specail smell. Ferulago species are named as "çaksırotu", "kisnis", "asaotu", "kuzu bası" and "kuzu kemirdi" in various regions of Turkey. The essential oils of secondary metabolits are encountered in the plants growing in the hot climatic regions of the world. Although these so called 'essence' and 'etheric oils' named owing to their smells are present in 100 families' species comprising the one third of the world flora, they are especially seen in some families of Coniferaea, Rutaceae, Apiaceae, Myrtaceae and Labiatae, mainly in their specific tissues 
(Graikou et. al. 2012;Mammadov 2014; Jara Bermeo et. al. 2016).

Essential oils (EOs) are known to exhibit antibiotic and anticeptic effects. With this special characteristics, they are called as antimicrobial agents since they are the alternatives to the food originated pathogens, chemical preservatives and antibiotics and they can destroy bacteria, fungia and yeast (Kürekçi and Sakin 2017).

Antioxidant compounds have the effect of delaying or inhibiting the oxidation of lipids and other parameters. The association of the myriad of compounds present in essential oil provides higher antioxidant activity than the summed activity of the individual components. Essential oils may also be used as food preserving agents owing to the presence of phenolic compounds as main components, which are liable to the antioxidant properties and may be an alternative to synthetic antioxidants (Marin et. al. 2016).

\section{Material and Methods}

\subsection{Materials}

For the current study, all parts (root, stem, leaf and flower) of Ferulago galbanifera (Mill.) W. Koch plant were collected. The collection area was Alpagut neighbourhood, Mihalgazi town (Eskișehir). After collection the samples were cleaned and dried for 7 days and Some of them were made into herbarium material (M. Sağıroğlu 6568 SAÜ Biology Herbarium).

All the chemicals and reagents (FolinCiocalteu, Gallic Acid, 2,2-diphenyl-1picrylhydrazyl (DPPH), Methanol, Mueller Hinton Agar ( $\mathrm{MH}$ agar), Triptic Soy Broth, Sodium Carbonate, Ascorbic Acid) used in this study were of analytical grade and obtained from Merck Company, Germany.

\subsection{Preparation of Extracts}

Fifteen grams of dried parts (roots, stem,leaf and flower) of the plants were ground into a capped bottle and $150 \mathrm{~mL}$ of ethanol and acetone was added on top of those. These prepared extracts are kept in a cool and dark environment for 3 days and mixed in a magnetic stirrer at regular intervals. The solvents in the extracts were evaporated by using a rotary evaporator (Heidolph) under vacuum at $55^{\circ} \mathrm{C}$ for 15 minutes and the dried extracts were then used for all investigations. The extract concentrations were adjusted by adding own solvent (ethanol or acetone) to each extract at the doses of $6400 \mu \mathrm{g} /$ disc for the antimicrobial activity tests. Ethanolic exracts were setting $1000 \mu \mathrm{g} / \mathrm{ml}$ for the antioxidant activity and the total phenolics analyses. For antimicrobial activity, $15 \mu \mathrm{L}$ of empty sterile discs with a radius of $6 \mathrm{~mm}$ from the raw extracts obtained were absorbed and kept in a dark sterile environment for 24 hours.

\subsection{Disc diffusion method}

All strains used throughout this study have been obtained from Microbiology Research Laboratory of Sakarya University. The disc diffusion method was used to determine the antimicrobial activities of the extracts. Suspensions with a density of 0.5 McFarland from previously activated microorganisms were prepared by a densitometer. Prepared microorganism suspensions to Müeller Hinton Agar were inoculated with sterile swab. Discs impregnated with extracts were slightly pressed on the inoculated plates under aseptic conditions, followed by an incubation at $37^{\circ} \mathrm{C}$ for $24 \mathrm{~h}$. Ethanol and acetone impregnated discs were used as negative controls and the commercial antibiotic discs (Gentamicin and Amphotericin B) were used as positive ones. If there is an inhibition zone against that pathogen around the disc as a result of the incubation, the zone diameters $(\mathrm{mm})$ are 
measured from the rear of the petri by using a digital caliper.

\subsection{Antioxidant activity (DPPH assay)}

The modified Blois method was used for determination antioxidant activity (Blois, 1958). In short, $1 \mathrm{ml}$ of $0.004 \%$ solution of DPPH radical in methanol was mixed with 1 $\mathrm{mL}$ of extract solution in methanol (containing different concentrations of dried extract). These solutions were kept in dark place for 30 mins and the optical density was then measured at $517 \mathrm{~nm}$ using a spectrophotometer and methanol was used for the blank. The following equation was employed to evaluate the \% DPPH radical scavenging activity: \%DPPH radical scavenging $=[$ (control absorbance- extract absorbance)/control absorbance] x 100.

\subsection{Total phenolic content (TPC)}

Total phenolic substance determination was determined using modified Folin-Ciocalteu method of Singleton and Rossi (1965). Taking $100 \mu \mathrm{L}$ of the prepared extract, $200 \mu \mathrm{L}$ of $50 \%$ Folin-Ciocalteu reagent was added and left for 2 minutes. We have then added $1 \mathrm{~mL}$ of $2 \% \mathrm{Na}_{2} \mathrm{CO}_{3}$ solution on it and waited for 1 hour in the dark and the absorbance at 760 $\mathrm{nm}$ was read. The total phenolic content was determined in mg / 100g using Gallic Acid Standard.

\section{Results and Discussion}

The polyphenolic constituents that are present in the plant extracts produce various biologic activities together with antioxidant abilities. Nowadays, several studies are focused upon the potential healt benefits of polyphenols and their pharmacological potential as antidiabetic (Asgar, 2013), anticancerogenic (Rosa et al., 2016), antimicrobial and antioxidant (Semerci et al., 2020) agents (Unuofin et al., 2017). In the current study, the extracts obtained from the root, stem, leaf and flower parts of $F$. galbanifera has been worked out for their phenolic contents and the results were given in Table 1 . The highest total phenolic content has been observed at the root part, whereas the lowest was at the leaf of the plant. The amount of the content were as follows: root 611.6 , flower 311.6 , stem 176.6 and leaf $43.4 \mathrm{mgGA} / 100 \mathrm{~g}$.

In vitro antioxidant tests are designed to imitate the oxidation-reduction reaction that are prevalently present in live biological systems and to evaluate the antioxidant potential of various chemical and biological substances (Ebrahimabadi et al., 2010). In this study a common DPPH test to measure the antioxidant activity has been employed. $\mathrm{IC}_{50}$ values of the extract obtained and the standard (value needed for scavenging the DPPH 50\%) are given in Table1. It has been determined that the highest antioxidant activity level is for flower ethanolic extracts (16.3 $\mu \mathrm{g} / \mathrm{mL})$. When compared with the ascorbic acid standard, it has been found that the flower extract exhibits higher level of antioxidant activity. To our best of knowledge, there is no any study indicating that the plant F. galbanifera has antioxidant activity.

Table 1. Antioxidant activity and total phenolic content of the samples

\begin{tabular}{lcc}
\hline Samples & $\begin{array}{c}\text { Antioxidant Activity } \\
\mathrm{IC}_{50}(\mu \mathrm{g} / \mathrm{mL}) \pm \mathrm{SD}\end{array}$ & $\begin{array}{c}\text { Total Phenolic Content } \\
(\mathrm{mgGA} / 100 \mathrm{~g}) \pm \mathrm{SD}\end{array}$ \\
\hline Flower & $16.32 \pm 0.28$ & $311.6 \pm 2.5$ \\
Stem & $244 \pm 0.8$ & $176.7 \pm 8.7$ \\
Root & $323.6 \pm 2.4$ & $611.6 \pm 7.75$ \\
Leaf & $215 \pm 1.4$ & $43.4 \pm 1.8$ \\
Ascorbic Acid & $3.2 \pm 00.1$ & - \\
\hline
\end{tabular}


Table 2. Antimicrobial activity of different parts of Ferulago galbanifera

\begin{tabular}{|c|c|c|c|c|c|c|c|c|c|}
\hline \multirow{2}{*}{\multicolumn{2}{|c|}{$\begin{array}{c}\text { Samples } \\
6400 \mu \mathrm{g} / \mathrm{disc}\end{array}$}} & \multicolumn{8}{|c|}{ Test microorganism (inhibision zone diameters, $\mathbf{m m} \pm \mathrm{SD}$ ) } \\
\hline & & \multirow{2}{*}{$\frac{\text { Ec }}{10.5 \pm 0.5}$} & \multirow{2}{*}{$\frac{\text { Se }}{0}$} & \multirow{2}{*}{$\frac{\text { Ef }}{0}$} & \multirow{2}{*}{$\begin{array}{c}\text { Bs } \\
8.5 \pm 0.5\end{array}$} & \multirow{2}{*}{$\frac{\mathbf{P a}}{8 \pm 0}$} & \multirow{2}{*}{$\begin{array}{c}\text { Sa } \\
12.5 \pm 05\end{array}$} & \multirow{2}{*}{$\begin{array}{c}\text { St } \\
9.5 \pm 0.5\end{array}$} & \multirow{2}{*}{$\frac{\mathbf{C a}}{0}$} \\
\hline $\bar{\pi}$ & Acetone & & & & & & & & \\
\hline$\stackrel{0}{\hookrightarrow}$ & Ethanol & $13 \pm 0$ & $10.5 \pm 0.5$ & $9 \pm 0$ & $9 \pm 0$ & $8 \pm 0$ & $16 \pm 0$ & $13 \pm 0$ & $8,5 \pm 0.5$ \\
\hline \multirow{2}{*}{ 离 } & Acetone & 0 & 0 & 0 & 0 & 0 & $8.5 \pm 0.5$ & 0 & 0 \\
\hline & Ethanol & 0 & 0 & 0 & 0 & 0 & 8 & 0 & 0 \\
\hline \multirow{2}{*}{$\begin{array}{l}\grave{0} \\
\grave{a} \\
\frac{0}{I}\end{array}$} & Acetone & 0 & 0 & 0 & 0 & 0 & 0 & 0 & 0 \\
\hline & Ethanol & 0 & 0 & 0 & 0 & 0 & 0 & 0 & 0 \\
\hline \multirow{2}{*}{$\begin{array}{l}\vec{\circ} \\
\stackrel{\circ}{\circ}\end{array}$} & Acetone & 0 & 0 & 0 & 0 & 0 & 0 & 0 & 0 \\
\hline & Ethanol & 0 & 0 & 0 & 0 & 0 & 0 & 0 & 0 \\
\hline \multirow{2}{*}{ 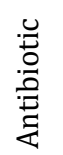 } & GC & 17 & 20 & 19 & 22 & 20 & 21 & 21 & 0 \\
\hline & Amp & 0 & 0 & 0 & 0 & 0 & 0 & 0 & 16 \\
\hline
\end{tabular}

Ec: Escherichia coli, Se: Staphylococcus epidermidis, Ef: Enterococcus faecalis, Ca: Candida albicans, Bs: Bacillus subtilis, Pa: Pseudomonas aeruginosa, Sa: Staphylococcus aureus, St: Salmonella typhimurium, Gc: Gentamicin, Amp: Amphotericin B.

Mileski et al. (2015) studied the antimicrobial adn antioxidant activities of endemic species of $F$. macedonica. They have concluded that the $\mathrm{IC}_{50}$ value of the extract obtained with ethanol was $1100 \mu \mathrm{g} / \mathrm{mL}$. Golfakhrabadi et. al. (2016) worked out the antioxidant/antimicrobial activity of Ferulago carduchorum plant and found that the extract obtained for the flower part with methanol has $\mathrm{IC}_{50}$ value of $1 \mathrm{mg} / \mathrm{mL}$, whereas it was $9.4 \mathrm{mg} / \mathrm{mL}$ when compared with hexan. It has been deduced that the solvent used in the extract preparation process does affect the antioxidant activity level.

In the current study it has been determined that the prepared leaf ethanolic extract has the IC 50 value of $215 \mu \mathrm{g} / \mathrm{mL}$. The difference between the works in the literature and the current one is thought to be originated from the extract preparation techniques and the plant collection areas, as well as the differences in species worked on.

The antioxidative and antimicrobial properties of essential oils obtained from several plants have taken great interest in academic studies and in food, cosmetics and pharmaceutics industries since they are thought to be the natural dopant substance candidates to substitute the synthetic antimicrobial agents. In that work, the antimicrobial activity effect of the extracts obtained from $F$. galbanifera plant (with acetone and ethanol) on Escherichia coli (ATCC 25922), Staphylococcus epidermidis (ATCC 12228), Enterococcus faecalis (ATCC 29212), Candida albicans (ATCC 10291), Bacillus subtilis (ATCC 6633), Pseudomonas aeruginosa (ATCC 27853), Staphylococcus aureus (ATCC 29213), Salmonella typhimurium (ATCC 14028) strains has been 
summarized in Table 2. The highest antimicrobial activity has been detected for the leaf extract (with ethanol) on the bacteria $S$. aureus, producing $16 \mathrm{~mm}$ inhibition diameter. Ethanolic extract is found to have higher antimicrobial activity level than acetonic extract one.

Demirci et al. (2000) studied the antimicrobial effects of the essential oils of various Ferulago species and found that the highest antibacterial effect of $F$. galbanifere essential oil was detected to be on $E$. coli, followed by $S$. aureus, $S$. typhimurium bacteria. In another work, the chemical constituents and antimicrobial activities of essential oils obtained from the root, stem, leaf and flower parts of $F$. trifida were investigated and concluded that the flower part has produced $18 \mathrm{~mm}$ inhibition zone on $S$. aureus, whereas it was measured to be 34 , 25 and $20 \mathrm{~mm}$ for the stem, the leaf and the root part, respectively (Tavakoli et al., 2017). In the current work, the highest antibacterial activity has been detected to be in $S$. aureus bacteria, though small differences between the parts of the plant. These antimicrobial activity differences in the various parts of the plants is thought to be originated from the fact that the chemical constituents differs in different part of the plants. Shivering the different parts of the plants in the preparation process of the extracts may create distinctive effects. In that work and the literature support this fact (Shaid Ud-Daula et al., 2016; Asraf et al., 2018).

\section{Conclusion}

The flower part of Ferulago galbanifera extracts show strong antioxidant activity due to its distinct content. From the current work together with the similar studies in the literature we conclude that different parts, i.e., flower, stem and leaf, of $F$. galbanifera are suitable to be used as a natural antioxidant and some (leaf part) as antibacterial source. The extract prepared from the leaf was determined to have a significant antibacterial effect on $S$. aureus. In this context, $F$. galbanifera leaves can contribute to natural hand and surface disinfectants and can be used as a food preservative

\section{Conflict of Interest}

The authors declare that they have no conflict of interest.

\section{References}

1. Akalın, E. (1999), Türkiye'nin Batısında Yetişen Ferulago Türleri Üzerinde Farmasötik Botanik Araştırmalar, İstanbul Üniversitesi Sağlık Bilimleri Enstitüsü, Doktora Tezi

2. Asgar, A., (2013), Anti-Diabetic Potential of Phenolic Compounds: A Review, , International Journal of Food Properties, 16:1, 91-103,

3. Ashraf, I., Zubair, M., Rizwan, K., Rasool, N., Jamil, M., Khan, S.A., Tareen, R.B., Ahmad, V. H., Mahmood, A., Riaz, M., Haq, M. Z. H., Jaafar, H. Z., (2018), Chemical composition, Antioxidant and Antimicrobial Potential of Essential Oils from Different Part of Daphne Mucronata Royle, Chemistry Central Journal 12:135

4. Başer, C. H. K., Demirci, B., Özek, T., Akalın E., Özhatay, N. (2002), Micro-Distilled Volatile Compounds from Ferulago Species Growing in Western Turkey, Pharmaceutical Biology, 40(6), 466-471

5. Blois, M.S. (1958). Antioxidant determinations by the use of a stable free radical. Nature, 181, 11991200.

6. Demirci, F., İşcan, G., Güven, K., Kirimer, N., Demirci, B., Bașer, K. H. C., (2000), Antimicrobial Activities of Ferulago Essential Oils, Z. Naturforsch. 55c, 886-889

7. Ebrahimabadi, A. H., Djafari-Bidgoli, Z., Mazoochi, A., Kashi, F. J., Batooli, H, (2010), Essential Oils Composition, Antioxidant And Antimicrobial Activity of The Leaves And Flowers Of Chaerophyllum Macropodum Boiss, Food Control 21

8. Golfakhrabadi, F., Ardekani- Shams, M.R., Saeidnia, S., Yousefbeyk, F., Jamalifar, H., Ramezani, N., Akbarzadeh, T., Khanavi, M., (2016), Phytochemical Analysis, Antimicrobial, Antioxidant Activities And Total Phenols Of Ferulago Carduchorum İn Two Vegetative Stages (Flower And Fruit), Pak. J. Pharm. Sci., Vol.29, No.2

9. Graikou, K. Gortzi O. Mantanis G. Chinou L. (2012) Chemical composition and biological activity of the essential oil from the wood of Pinus heldreichii 
Christ. var. Leucodermis. Eur. J. Wood Prod. (2012) 70:615-620

10. Jara Bermeo A. Penailillo P. San martin A. Malagon O. Gilardoni G. Gutierrez M. (2016). Chemical Composition And Antıbacterial Actıvity of Essential Oıls From Azorella spinosa (Apraceae) Against Wild Phytopathogenıc Bacteria. J. Chil. Chem. Soc., 61, № 4

11. Kürekçi, C., Sakin, F., (2017), UçucuYağlar: Antimikrobiyal Açıdan Uçucu Yağlar: In-Vitro ve In-Vivo Çalışmalar, Turkiye Klinikleri J Anim Nutr\&Nutr Dis-Special Topics 2017;3(1):15-20

12. Mammadov, R. (2014), Tohumlu Bitkilerde Sekonder Metabolitler, Ankara, ( Nobel Akademik Yayıncllık), 67-285

13. Marin, I., Sayas-Barbera E., Viuda-Martos, M., Navarro, C., Sendra, E. (2016), Chemical Composition, Antioxidant and Antimicrobial Activity of Essential Oils from Organic Fennel, Parsley, and Lavender from Spain, Foods, 5, 18.

14. Mileski, S. K., Džamić M. A., Ćirić D. A., Ristić S. M., Grujić S. M., Matevski V. S., Marin P. D., (2015), Composition, Antimicrobial and Antioxidant Properties of Endemic Species Ferulago macedonica Micevski \& E. Mayer, ACG Publications, 9:2,208-223

15. Rosa, L. S., Silva, N. J. A, Soares, N. C. P., Monteiro, M. C., Teodoro, A. J., (2016), Anticancer Properties of Phenolic Acids in Colon Cancer - A Review, J Nutr Food Sci, 6:2

16. Saya Ö. (2012). Ferulago Koch Şu Eserde: Güner, A., Aslan, S., Ekim, T., Vural, M., Babaç, M.T. Türkiye Bitkileri Listesi (Damarlı Bitkiler), İstanbul: ANG Vakfi/Nezahat Gökyiğit Botanik Bahçesi, 2012.

17. Semerci, A. B., Tunç, K., Okur, İ., (2020), Antioxidant activity of the fruits of Pyracantha coccinea using ethanolic extract method, Food and Health, 6(1), 35-40

18. Shaid Ud-Daula, A.F.M., Demirci, F., Salim, K.A., Demirci, B., Lim, L. B. L., Baser, K. H. C., Ahmad, N., (2016), Chemical Composition, Antioxidant and Antimicrobial Activitis of Essential Oils from Leaves, Aerial Stems, Basal Stems, and Rhizomes of Etlingera Fimbriobracteata (K. Schum.) R. M. Sm., Industrial Crops and Products 84, 189-198

19. Singleton, V.L., Rossi, J.A. (1965). Colorimetry of total phenolics with phosphomolybdicphosphotungstic acid reagents. American Journal of Enology and Viticulture, 16, 144-158.

20. Tavakoli, S., Yassa, N., Delnavazi, M. R., Akhbari, M., Hadjiakhoondi, A., Hajimehdipoor, H., KhalighiSigaroodi, F., Hajiaghaee, R., (2017), Chemical composition and biological activities of the essential oils from different parts of Ferulago trifida Boiss, Journal of Essential Oil Research, 29:5, 407-419
21. Unuofin, j. O., Otunola, G. A., Afolayan, A. J., (2017), Phytochemial Screening And İn Vitro Evaluation Of Antioxidant And Antimicrobial Activities of Kedrostis Africana (L.) Cong, Asian Pac J Trop Biomed 7(10): 901-908 